\title{
The Implication of Authentic Assessment by Lecturers/Teachers in Era 4.0;A Model for Switching Era
}

\author{
Elsina Sihombing \\ IAKN Tarutung, North Sumatera Indonesia \\ elsinasihombing@gmail.com
}

\begin{abstract}
In Indonesia especially in its educational scope, the term 4,0 industrial revolution is a bit challenging for almost all various levels of educators, some of them are shocking since they used to use conventional methods of teaching which are out of date as 4.0 industry requires them to do in encountering millennial students during learning process. Henceforth, no other choices to take except existing themselves and the ways of their teaching to real condition as what they encounter to. Authentic assessment is a distinguisher segment of K-'13 against the former curriculum, that helps the educators out of their obscurity to assess. The result shows that t-test in which t-obtained (4.6) was further exceeds $\mathrm{t}$-tab $(2.518$ at $\alpha=1 \%)$ and 1.725 at $\alpha=5 \%)$ which is symbolizing with: $1.725<4.6>2.528$. in (df) 20 (22-2).It implies thatthe developed model is significantly effective to use.
\end{abstract}

Keywords:.Switching model, fundamental national curriculum, AuthentiAssessment, Era 4.0

\section{Introduction}

In every maneuver of the curriculum, the teachers were certainly heading up to the goal or objective of every running curriculum. Different curriculum period needs different goals or objectives, and of course different content, see Zais ( 1996 ). This condition could influence the teacher steadiness to run the changing goals, from K-'13 to KTSP and back to K-'13 (revision) each in a short period.

Bearing with K-' 13 curriculum, the most essential key point as the icon of this curriculum is that one of its segment namely the measurement standard emphasizing on using authentic assessment to measure the learners achievement during the learning process. In this case, authentic assessment recommends Contextual Teaching and Learning (CTL), and Scientific learning as the approaches of learning at schools. It is generally evidence that contextual learning is claimed as a concept of learning in which the teacher help the students to parallelize the content of learning to the real context around the society and togetherly tailoring the knowledge to the students so that they can actualize it in daily life, see (Permendikbud, 2013). Contextual learning is a holistic and integrated learning process in which the teacher nurturing the learners to master the content and parallelize it to their daily real life. Hence, basically this approach emphasizes the importance of content and life reality parallelism of which the learners as the part. Whereas, scientific learning approach is learning process that emphasizing on empirical creativity and innovation using methods of inquiry in 5 steps: observing, asking, logical thinking, exploring, and collaborating to sharpen the 3 golden domains of learners' faculty namely: affective domain, cognitive domain, psychomotor 
domain see, Permendikbud no. 65 (2013). According to the writer the three golden domains of human can be designed as the following picture:

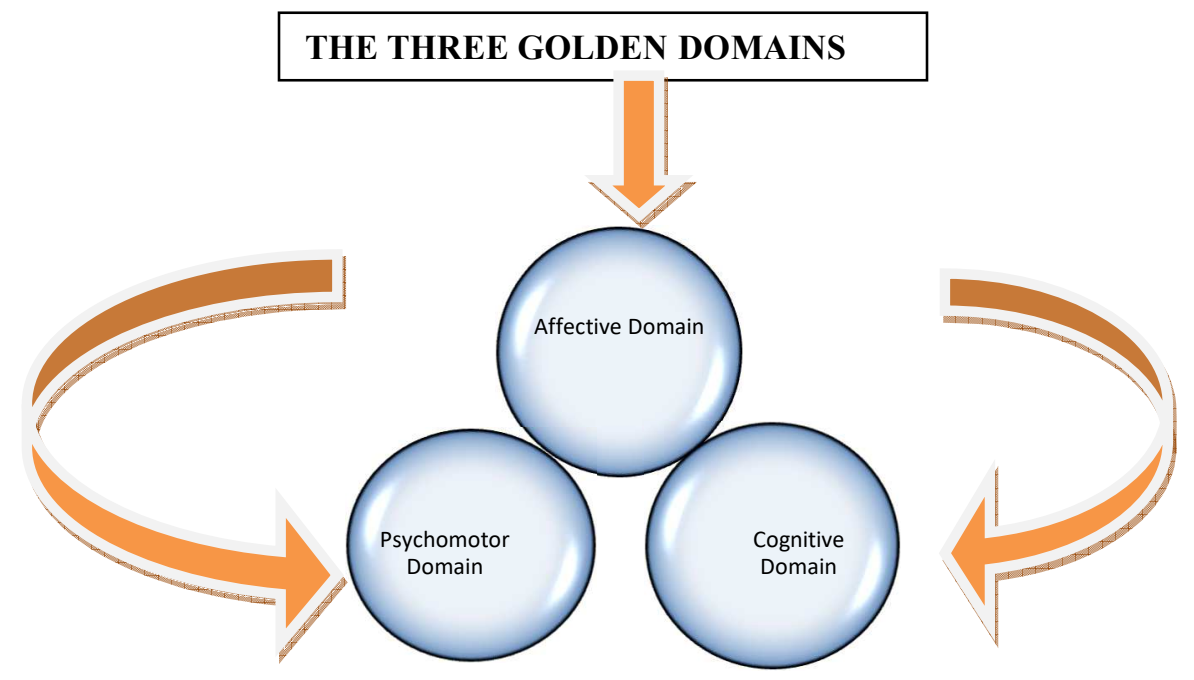

Fig.1. The three golden domains of human (by: Elsina Sihombing)

As a matter of fact, in Indonesia the system of assessment is rather weak practically, especially in test design and the rubric of scoring. Whereas, in Indonesia Government regulation, No. 20 by the year of 2007 about standard of Educational Assessment stated that Indonesia ministry for the purpose of controlling the quality of education based on the national standard of education which is developed by BNSP (National Education Standard Deputy), see The Regulation of Indonesia Government No. 17 by year $2010(2010 ; 787)$. It is emphasizedin K-'13 that there are 8 national standards of education, one of them is the standard of educational assessment.

The problem of the study is that there were many teachers/lecturers who did not understand, did not know what should be scored from the students learning as theauthenticity of learning especially concerning to the era 4.0 namely the industrial revolution around the world, the researcher thought that it was important to release such a vagueness and obscuritybecause it is also one of the ways of how to save Indonesia Education heading toward the certain and the best education. To solve such a complicated messy thought of the teachers/Lecturers all around Indonesian educational institutions, the researcher intent to help them and the Government, as well to present a solution by presenting a guide-book of authentic assessment bolding on scoring rubric, as the novelty of the research to dedicate as the writer contribution in educational field. Deriving fromo the stem of the term, industry 4.0 is a means of smart factory, Morrar Rabeh (2017). In fact, throughout thesmart factory,decentrilized decision making can be developed and a virtual copy of the physical world, and furtherphysical system can cooperate and communicate with each other and with human beings in real time, it is of course empowering by internet tools and related services. Generally, the impact of industry 4.0 boosting the influences to intense of digitization. Basically, the concept ofindustry 4.0 starting from Germany and has been recognized by other nations which as leading industrial nations in the world, known asConnected Enterprise in 
United States, and The fourth Industrial Revolution in United Kingdom. To view the existence of industrial revolution 4.0, it is important to trace back that industrial technology 4.0 has been derived from the 3 preceeding technological transformations :At the period of 1.0 it was known assteam power, of which the transformative force took a room during nineteenth century: at the period of 2.0 it was known as electricity, $t$ of which the transformative force took a room during the twentieth, andat the period of 3.0 it was known as computer booming, thisera of the computer beginning in1970s,see Cordes \& Stacey, (2017).

\section{Result and Discussion}

In the last two eras, Indonesia curriculum has been focused andperiodically changed, and the reasonable issues for the changes is improvement. In each of the change wasnot a total change, but the partial one, instead. The last 2periodical curriculums are; KTSP (2006), and K-'13. All the changes needed the educators' participation in engaging the learners to be the most activated in the process during the learning period, as the pay-of, the educators should bemuch more well-prepared, steady, righteous, eligible and in concordance with Indonesia education system. As a matter of fact, in every maneuver of the curriculum, the teachers were certainly heading up to the goal or objective of every running curriculum. Different curriculum period needs different goals or objectives, and of course different content, see Zais (1996). This condition could influence the teacher steadiness to run the changing goals, from K-'13 to KTSP and back to K-'13 (revision) each in a short period. It made all the teachers being confused and did not know what to do to fulfill what the last curriculum (K-'13 revision) demands especially dealing with assessment and evaluation. Regarding the problem background above, it is fair enough to bolden the general problem of this study, it is: "What is the appropriate model of scoring rubric of authentic assessment for English teachers at senior high schools, Indonesia?". Then, inductively it was centrally elaborated into the following research questions:

a) Whatis the English teachers' perception about authentic Assessment before and after theresearch?

b) How important is the teachers' need towards developed scoringrubric of authentic assessment and why they need itfundamentally?

c) On what ways do the teachers/lecturers can develop a model of authentic assessment ofEnglish scoring rubric?

d) What is the experts (validators) opinion towards developed modelof scoring rubric of authentic assessment for senior high schoolEnglish teachers in Lubuklinggau?

e) What is the validity, reliability, and practicality of the developed model?

Since assessment is a means of process evaluation, it is ongoing process of measurement dealing with the learners' learning during their period of study. According to Santrock (2007) that in the 1990s the teachers/lecturers were welcome and appreciatedto create form of standardized measurement, henceforth, there were many efforts to employee performance or authentic measures, of which the learners were required to demonstrate their achievement by producing authentic responses to evaluation tasks such as written and spoken answers, most of motoric performance by the learners or psychomotor presentation, portfolios of work product, group discussion and presentation in overcoming problems. All aimed to assess the 
authenticity is to make the students to master underlying understandings and skills that they can actualize in thir life.

Since this study applying mixed research method focusing on transformative concurrent technique, it was reasonable for the researcher to analyze the data from the two resources embeddedly; qualitative data were prior to quantitative data. Quantitative data were displayed to empower the data for the purpose of gaining the product accountability, as the result of this research. Data that collected byquestionnaire were analyzed both in qualitative and quantitative methods, as well. The way of transforming the data qualitatively was certainly by interpreting the raw data using detailed empirical descriptionin easy-understood English.

Quantitatively, it was found that t-obt.: 4.6 was much exceeds t-tab at the degrees of freedom (df) $22-2=20$ with two-tail test on the significant level of either $\alpha 5 \%(1.721)$ or $\alpha$ $1 \%(2.518)$ or numerically it can be symbolized; $1.725<4.6>2$. 528. The interpretation of the result of the formula indicated that quantitatively alternative hypothesis $(\mathrm{Ha})$ was accepted and automatically null hypothesis (H0) was rejected, because t-obt significantly exceededt-tab with degrees of freedom (df) 20 (22-2) with two tailed test.

It can be interpreted that the instrument and the developed model were strong practically to use. The researcher stated the value of practicality for both instrumentation and the developed model togetherly, since the tabulated score that was administered by the formula, resourced from the score of pre-test and post-test which were contained questions about the content of the developed model. Shortly, the correlation of coefficient of the two tests in this study proved that both questionnaire and the developed model are significantly practical.

From the qualitative data, it was concluded that the designed scoring rubric that the teachers used was helpful for them to use as the authentic assessment. It didnot only make the English teachers know the authenticity of the assessment in K-'13, but it also inspired them to develope their own scoring rubric based on the guide book they have had as the result of this research.

On the phase of data reduction from both qualitative and quantitative methods, the researcher found the strong data to design the prototype of the model based on the responses from need analyses. The new design model of the scoring rubric as the authentic assessment then was sharpened by having trial-1 and revision-1 continued to trial-2 and revision-2, having validation in internal FGD, having minor scale dissemination.

From the experience of the teachers/lecturers of using the new designed model, it was clearly detected that K-, 13 curriculum for them was such an ambigious curriculum to run caused of their lack of understanding upon this new curriculum and the suddenly climate they encountered to run it without drills.From such a circumstance, the researcher found that there was an unmatched comprehension of the teachers/lecturers towards the former conventional curriculum to the newest one which was not familiar with. The unmatched conventional model became a problem and dilemma for the teachers, whereof, they run the newest curriculum but they implicate the conventional assessment system, as the essential part of the curriculum itself. This was the key-point for the writer to take action, take place and take the time to contribute on how to overcome and what solution was the best way to help the teachers/lecturers, so that they are able to encounter and and run the new curriculum for the sake of Indonesia qualified education and generation.

Since the research conducted was a part of $R \& D$ an the basis of product research, henceforth, the research result as the product of the research itself was designed in the form of a book which is named as: English Scoring Rubric of Authentic Assessment; A Guide Book for The Teachers. In creating this guidebook for the teachers, it is hopefully that by using this 
book, the teachers/lecturers are helped out of their problem in running the K-,13 curriculum especially to implicate the authenticity of learning and evaluating.

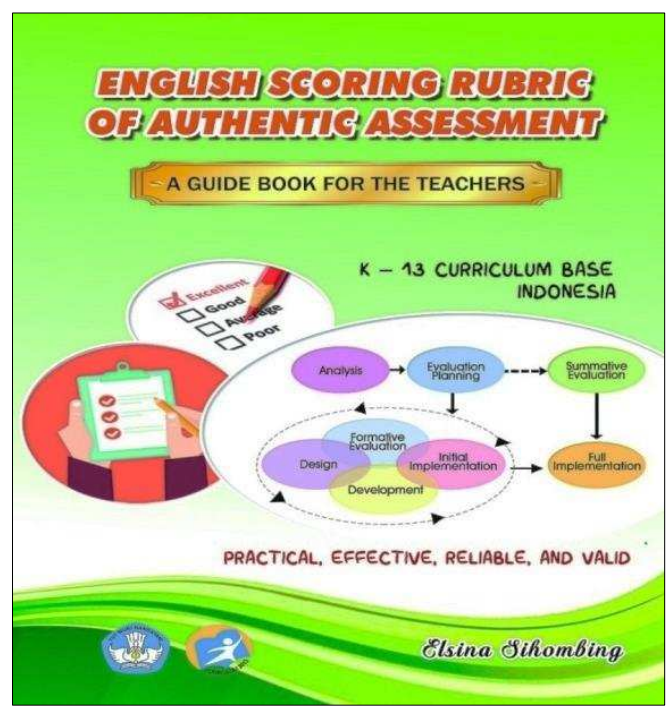

Fig.2. The form of the guidebook

By having and implicating the guidebook, the writer and the valodators believe that the teachers/lecturers with various background and different subject matters can improve the way and the quality of their teaching or learning, and automatically improve the quality of the learners. Herewith, the table below can bridge out, how to figure out the teachers ambigious towords the newest curriculum in Indonesia which is named K'13 curriculum.

The unmatched components of the conventional model were shown as the following:

Table 1. Conventional vs K-' 13 curriculum source : PPRIno.17, 2013

\begin{tabular}{|c|c|c|c|c|}
\hline No & $\begin{array}{l}\text { Contents of } \\
\text { Assessment }\end{array}$ & Conventional model & K-'13 model & New Model \\
\hline 1 & $\begin{array}{l}\text { Authentic } \\
\text { assessment } \\
\text { measuring the } \\
\text { process as } \\
\text { a whole }\end{array}$ & $\begin{array}{l}\text { Assessment was } \\
\text { emphasized on } \\
\text { paper/pencil test. }\end{array}$ & $\begin{array}{l}\text { The process was integrated } \\
\text { in other components }\end{array}$ & $\begin{array}{l}\text { Assessment was } \\
\text { emphasized on the learning } \\
\text { process which is integrated } \\
\text { in the } 3 \text { domains; } \\
\text { affective,cognitive, and } \\
\text { psychomotor domains. }\end{array}$ \\
\hline 2 & Attitude & $\begin{array}{l}\text { Only } 2 \text { subject matters } \\
\text { assessing attitude, and } \\
\text { the way of measuring } \\
\text { was not objective, } \\
\text { focusing for casuistic } \\
\text { learners, only. The } \\
\text { learners without any } \\
\text { cases got scoring } \\
\text { predicateon A, or B. }\end{array}$ & $\begin{array}{l}\text { All subject matters } \\
\text { assessing attitude } \\
\text { objectively during the } \\
\text { process of learning, } \\
\text { Scoring predicate decision } \\
\text { is based on the strong or } \\
\text { weak positive character } \\
\text { they have. All is observed } \\
\text { throughout behavior } \\
\text { observation form. }\end{array}$ & $\begin{array}{l}\text { English and other } \\
\text { lainguages measure } \\
\text { attitude boldenly and it is } \\
\text { as the main and the first } \\
\text { domain to measure, inorder } \\
\text { all the learners possess } \\
\text { good characters as the } \\
\text { result of learning that can } \\
\text { be actualized in daily life. }\end{array}$ \\
\hline 3 & $\begin{array}{l}\text { Cognitive } \\
\text { scoring rubric }\end{array}$ & $\begin{array}{l}\text { Cognitive scoring was } \\
\text { done based on the }\end{array}$ & $\begin{array}{l}\text { Teachers must design } \\
\text { scoring rubric to make }\end{array}$ & $\begin{array}{l}\text { It is very important to } \\
\text { design a new model based }\end{array}$ \\
\hline
\end{tabular}




\begin{tabular}{|c|c|c|c|c|}
\hline No & $\begin{array}{l}\text { Contents of } \\
\text { Assessment }\end{array}$ & Conventional model & K-'13 model & New Model \\
\hline & & $\begin{array}{l}\text { teacher's logical } \\
\text { thinking without } \\
\text { rubric, no standard to } \\
\text { give score } 40,75 \text {, or } \\
100 .\end{array}$ & $\begin{array}{l}\text { assessment system being } \\
\text { objective, but there is no } \\
\text { pattern or model to follow. }\end{array}$ & $\begin{array}{l}\text { on the K-13 suggestion. } \\
\text { The new model is available } \\
\text { as the product of this } \\
\text { research }\end{array}$ \\
\hline 4 & $\begin{array}{l}\text { Cognition } \\
\text { assessment }\end{array}$ & $\begin{array}{l}\text { It was not integratedly } \\
\text { assessed along the } \\
\text { process of learning. }\end{array}$ & $\begin{array}{l}\text { It must be integratedly } \\
\text { assessed along the process } \\
\text { of learning, but there isn't } \\
\text { any example. }\end{array}$ & $\begin{array}{l}\text { In this new model, there } \\
\text { are hints and examples of } \\
\text { how to develop cognitive } \\
\text { assessment. }\end{array}$ \\
\hline 5 & Psychomotor & $\begin{array}{l}\text { It was saparatedly } \\
\text { measured at an } \\
\text { uncertain timing, the } \\
\text { scoring has no } \\
\text { standard as the rubric } \\
\text { of psychomotorwhich } \\
\text { was similar to action } \\
\text { along the process }\end{array}$ & $\begin{array}{l}\text { It should be integratedly } \\
\text { measured in all sides of the } \\
\text { learners work: in product } \\
\text { (portfolio) assessment and } \\
\text { in project assessment, peer } \\
\& \text { self assessment, and at } \\
\text { the cognition test. } \\
\text { Measuring psychomotor } \\
\text { should be on the basis of } \\
\text { certain scoring rubric. }\end{array}$ & $\begin{array}{l}\text { Supported by K-' } 13 \\
\text { description about } \\
\text { psychomotor assessment, it } \\
\text { was preferable to illustrate } \\
\text { by usingthe } 6 \text { segments of } \\
\text { scoring rubric in this new } \\
\text { model. }\end{array}$ \\
\hline 6 & $\begin{array}{l}\text { Peer \& Self } \\
\text { assessment }\end{array}$ & $\begin{array}{l}\text { These } 2 \text { components } \\
\text { were not taken in } \\
\text { account as one ofthe } \\
\text { authenticity of } \\
\text { assessment in K-'13 } \\
\text { curriculum. The three } \\
\text { scoring domains were } \\
\text { not involved namely; } \\
\text { affective, } \\
\text { cognitive, and } \\
\text { psychomotor ability. }\end{array}$ & $\begin{array}{l}\text { These } 2 \text { components are as } \\
\text { part of compulsory of the } \\
\text { authenticity of assessment } \\
\text { in K-'13 curriculum. The } \\
\text { three scoringdomains are } \\
\text { boldlyintegrated } \\
\text { insidenamely; } \\
\text { affective,cognitive, and } \\
\text { psychomotor ability are } \\
\text { measured. }\end{array}$ & $\begin{array}{l}\text { Theory and description are } \\
\text { not enough to familiarize } \\
\text { for the teachers, it needs } \\
\text { hints and exemplifying } \\
\text { how to develop a new } \\
\text { mode for such scoring } \\
\text { rubric. }\end{array}$ \\
\hline 7 & $\begin{array}{l}\text { Score } \\
\text { Accumulation }\end{array}$ & $\begin{array}{l}\text { The six segments of } \\
\text { authentic assessment of } \\
\text { K-' } 13 \text { were not } \\
\text { completely available. } \\
\text { Moreover, all the } \\
\text { faculties are not allowed } \\
\text { to be accumulated since } \\
\text { each of them is different } \\
\text { one another. }\end{array}$ & $\begin{array}{l}\text { The six segments of } \\
\text { authentic assessment are a } \\
\text { compulsory in K-'13 } \\
\text { curriculum and the } 3 \\
\text { domains are measured } \\
\text { integratedly in each of the } \\
\text { segment. It is only a theory } \\
\text { we can meet in K-' } 13 \text {. }\end{array}$ & $\begin{array}{l}\text { To help the teachers } \\
\text { understanding the theory in } \\
\text { K-'13, it is important to } \\
\text { design a new model based } \\
\text { on the theory above, } \\
\text { henceforth, they easily } \\
\text { develop their own scoring } \\
\text { rubric empirically. }\end{array}$ \\
\hline
\end{tabular}

\section{Conclusion}

The novelty of this study is, by the result of this research the senior high schools teachers in South Sumatera Indonesia felt fruitful since they got valuable knowledge of what authentic assessment is, and how to develop scoring rubric of authentic assessment based on K-'13 demands. Since the teachers were involved as the subject of this research,they have known well and even they are able to develop their own scoring rubric based on K-' 13 curriculum, and share the ways of how to create with other subject teachers.

Further more,regarding the assessment system of K-'13 curriculum Based on Permendikbud (2016; chapter IV; verse 6) scoring procedures covering the 3 domains:

a) Attitude. It can be measured by conducting an observation, record it academically, and the result is prescribed in description form. The attitude also can be measured 
throughout the six faculties of authentic assessment namely; observation (behavior assessment, product assessment (port folio), project assessment, self assessment, peer assessment, cognitive assessment.

b) Knowledge. It can measured by paper/pencil test (product) or by observing during the process (performance), and the result is prescribed in numerical range $(0-100)$. This domain is also integrated in the segments of authentic assessment.

c) Psychomotor. It can be measured throughout the process and product assessment, scoring it in numerical range and description.

\section{References}

[1] Bloxham \& Boyd.Developing Effective Assessment in Higher Education. New York. Open Univ. Press. (2007)

[2] Boundless. Maslow's Theory in Boundless Psychology. Retrieved by June 18th, (2016) fromhttps://www.boundless.com/psychology/textbooks/boundless-psychology.

[3] Burns, Robert. Research Method. Australia. Longman Australia Ptd, Ltd (1995)

[4] Finch A. E.A formative evaluation of a task based conversation PAC journal 1 (1) 125-146. (2001)

[5] Frankle \& Wallen. How To Design and Evaluate Research in Education. New York. McGrawHill Inc (2012)

[6] Gay, L.REducational Evaluation \& Measurement. London. Charles E. Merril Publishing Company (1980)

[7] Gay \& Airasian.,Educational Research. Ohio. Prentice Hall, Inc.(2000)

[8] Jackendoff, Ray.,Foundation of Language. New York. Oxford University Press (2003)

[9] Johnson \& Johnson., Meaningful Assessment. Sydney. Allyn \& Bacon Company (2002)

[10] Joyce \& Weil., Models of Teahing. London. Allyn and Bacon Publication (1992) 